\title{
Techniczno-leksykograficzna notatka o kompozycjach typu owocowo-warzywny
}

Słowa klucze: krytyka leksykograficzna; słowniki ogólne języka polskiego; kompozycje przymiotnikowe owocowo-warzywny; naukowo-badaw$c z y$ itp. jako wyrazy hasłowe i/lub podhasła

Key words: lexicographic critic; Polish monolingual dictionaries; compound adjectives; dictionary entries for the owocowo-warzywny type

W cieszącej się dużym uznaniem ${ }^{1}$ monografii Teresy Smółkowej o neologizmach we współczesnej leksyce polskiej (Smółkowa 2001) znajduje się specjalny rozdział poświęcony przymiotnikom. Uzupełnia go cenny, choć kontrowersyjny co do doboru haseł, aneks: indeks przymiotników wynotowanych z prasy okresu 1985-1992, liczący ponad 5500 pozycji (Smółkowa 2001: 133-185).

Jedna $\mathrm{z}$ pozycji tego indeksu to przykładowe złożenie owocowo-warzywny, umieszczone w tytule niniejszej notatki. Wyznacznikiem typowości owych złożeń uczynię tu pisownię, występowanie łącznika. Stron indeksu, na których by twory z dywizem nie występowały, jest niewiele, zaledwie

${ }^{1}$ Co się wyraża znaczną liczbą cytowań w literaturze naukowej i popularnonaukowej (zasadniczo, w danym wypadku, całkowicie bezkrytycznych). 
trzy czy cztery. Pisownia haseł indeksu jest oryginalna, zgodna z pisownią wykorzystanych źródeł prasowych. Większość przymiotników z łącznikiem zaprezentowanych $\mathrm{w}$ nim to wyrażenia jednodywizowe, niemniej z rzadka występują też „dwudywizowce” (jak cinkciarsko-peweksowo-delegacyjny, handlowo-ustugowo-rzemieślniczy), a nawet kompozycja trzydywizowa (małomiasteczkowo-rabinacko-szabasowo-mesjański). Trzydywizowość nie jest graniczna, we współczesnych tekstach polskich, które mogłyby stanowić podstawę ekscerpcyjną wytworów typu owocowo-warzywny, trafiają się sekwencje dłuższe, cztero-, pięcio-, sześcio- czy jedenastodywizowe.

Słowniki ogólne języka polskiego, od słownika Lindego do słownika Dubisza, nie podejmują kwestii przymiotników tak złożonych, jak np. włosko-francusko-angielsko-niemiecko-rosyjsko-czesko-polski (przykład realny, podtytuł pewnego wielojęzycznego słownika terminów muzycznych), przynajmniej od strony teoretycznej, tzn. w przedmowach towarzyszących tym słownikom brak o owych adiektywach - artykulacyjnie, pamięciowo i estetycznie tym kłopotliwszych, im więcej członów zawierają - jakichkolwiek informacji. Nie oznacza to jednak, że autorzy z góry uznali wszystkie niejednodywizowce za swobodne konstrukcje wyrazowe, nie mające prawa do figurowania w siatce haseł na równi z wyrażeniami dom, domek, pięć, piqteczka, ale i pięciopokojowy, pięćdziesięcioletni, pięćdziesięciokilkoletni ${ }^{2}$. W praktyce w słownikach hasła typu warzywno-owocowy występuja, choć z jednym istotnym ograniczeniem: jeśli już występują, to w zasadzie tylko jednodywizowce ${ }^{3}$ i, zupełnie zupełnie sporadycznie, dwudywizowce . $^{4}$

Brak refleksji teoretycznej nad statusem hasłownikowym jedno-, dwui więcejdywizowców jest oczywisty.

W tymże SWil. nie ma np. haseł cytrynowo-żólty, czarno-zielony, słodkawo-kwaskowaty, słowiańsko-pogański, ale same przymiotniki zostały w nim zarejestrowane, tyle że wewnątrz artykułów hasłowych, w cy-

2 Okazy w rodzaju tych trzech ostatnich dość regularnie rejestruje SJPDor.

3 Jest wszakże ciekawy wyjątek, potwierdzający regułę wykluczania z hasłowników dwu- i więcejdywizowców, mianowicie osobliwe hasło jedno-dwój-trój-czwórprzedimkowy, obecne w SWil. Mamy tu do czynienia z chwytem technicznym, kompresją zapisu wyrażenia pełnego czteroczłonowego: jednoprzedimkowy, dwójprzedimkowy, trójprzedimkowy, czwórprzedimkowy (notabene, żaden z tych przymiotników z osobna nie występuje w siatce haseł SWil.). Chwyt ten okazał się incydentalny, nie znalazł i słusznie - uznania wśród leksykografów.

${ }^{4}$ Dotyczy to przymiotników terminologicznych w SWarsz., o czym niżej. 
tatach i objaśnieniach (por., odpowiednio, artykuły: czarnuszka, krążnica, kokos, czart). Takie podejście, tj. ,,przemilczenie” w siatce haseł tworów cytrynowo-żółty, słowiańsko-pogański itp., jest właściwe.

Inaczej postapili autorzy Słownika warszawskiego. W dziele tym jest dużo złożonych przymiotników niehasłowych: naukowo-filozoficzny, naukowo-weterynaryjny, naukowo-wychowawczy (s.v. naukowy), przemysłowo-gospodarczy (s.v. przemysłowy), przemysłowo-rolny (tamże), zoologiczno-anatomiczny (s.v. zoologiczny), psychiczno-zmysłowy (s.v. psychiczny) ${ }^{5}$, ale jednocześnie zdarzają się jednak i hasła dywizowe, tylko jedno- i dwudywizowe. Oto ich „rodzinki” (znamienne, leksyka terminologiczna): hio-językowy, hio-tarczowy; mostko-gnykowy, mostko-grdykowy, mostko-łokciowy, mostko-obojczyko-sutkowy, mostko-obojczykowo-wymionowaty czy piersio-kluczo-cyckowy itp.

W siatce haseł SJPDor. kompozycji typu owocowo-warzywny brak. Niehasłowo zaświadczona jest odpowiednimi cytatami pewna liczba złożeń, jak fizyczno-geograficzny (nie w artykule fizyczny, lecz w środkowy), marksistowsko-leninowski (nie w marksistowski, lecz w robotniczy), robotniczo-chłopski (s.v. robotniczy), spiskowo-rewolucyjny (s.v. węglarstwo). Trudno tu mówić o doborze takich przymiotników, są to rejestracje przypadkowe, uwarunkowane całkowicie materiałem leksykalnym cytatów. Dopóki nie powstanie kompletny indeks wyrazów niehasłowych SJPDor. ${ }^{6}$, dopóty bardzo trudno jest odpowiadać na pytanie, czy słownik ten zarejestrował kompozycje górniczo-hutniczy, turystyczno-krajoznawczy, warzywno-owocowy, węgiersko-polski i inne, ponieważ brak ich w tych artykułach przymiotnikowych, z którymi korelują pierwsze człony kompozycyj ze specjalną fleksją - $o$.

Przymiotniki, współtworząc zdania, odmieniają się nie tylko przez rodzaje, liczby i przypadki. Regularnie łączą się z innymi przymiotnikami, dosłownie przyklejają się do ich nagłosu, przybierają postać na -o, nie tworząc nowego wyrazu. Wyrażenie warzywno-owocowy to nie jest nowy wyraz, derywat od podstawy owocowy, lecz kompozycja wyrazów, dwuwyrazowa syn-

5 Uwaga: przymiotnik psychiczno-zmysłowy odnotowany został w indeksie Smółkowej (2001); wcześniej, w artykule polityczny SWarsz., występują niehasłowo przymiotniki polityczno-administracyjny, polityczno-militarny, polityczno-społeczny, polityczno-wojskowy, również (niesłusznie) obecne na liście Smółkowej.

${ }^{6}$ Por. Wawrzyńczyk 2010. 
tagma warzywny + owocowy. Podobnie np. znana Norwidowska kompozycja mahometańsko-angielsko-protestancko-emigrancko-konstantynopolitański to nie nowy wyraz, to nie żaden nowy obiekt leksykograficzny (który by trzeba było zarejestrować i opisać w słowniku narodowym języka polskiego), lecz sekwencja pięciu wyrazów, graficzny czterodywizowiec, skrót rozwlekłego zapisu: mahometański + angielski + protestancki + emigrancki + konstantynopolitański.

USJP wyodrębnia jako samodzielne artykuły pozycje ekonomiczno-finansowy, owocowo-warzywny, przemysłowo-rolniczy, sanitarno-epidemiologiczny, społeczno-gospodarczy, warzywno-owocowy i kilkanaście innych, które definiuje za pomocą klasycznej koniunkcji znaczeń odrębnych wyrazów składających się na daną kompozycję-konstrukcję, np. lądowo-wodny to 'dotyczący lądu i wody', owocowo-warzywny to 'dotyczący owoców i warzyw, owocowy i warzywny'.

Fakt zaistnienia w tym czy innym słowniku artykułów z nagłówkami typu owocowo-warzywny ${ }^{7}$ byłby naganny wówczas, gdyby dany słownik został zaprojektowany przez autora czy autorów świadomie jako słownik językowy. Jednostki typu owocowo-warzywny nie są obiektami leksykograficznymi, one rozmywają słownik pod względem typologicznym, wnosząc doń informację encyklopedyczną. Jeśli leksykograf wpuszcza do hasłownika byty w rodzaju lądowo-wodny, to od razu skazuje się na niekonsekwencję i pretensje użytkownika, że w jego dziele brakuje dziesiątek i setek innych analogicznych kompozycji, jak górniczo-hutniczy, historyczno-literacki itp. Wprawdzie co do interpretacji semantycznej nie sprawiają one żadnego kłopotu, ale nie da się wykluczyć, że użytkownik słownika z założenia językowego potrzebuje hybrydy: słownika semantyczno-ortograficznofrazeologiczno-realioznawczego.

Typologiczną czystość słownika semantycznojęzykowego można utrzymać - jeśli traktować segmenty administracyjno-, górniczo-, informacyjno-,

7 Ale nie typu marksistowsko-leninowski, przygodowo-awanturniczy, którym w tej notce się nie zajmuję, ponieważ nie ma w tych kompozycjach prostej koniunkcji marksistowski + leninowski (podstawę derywacyjną pierwszego przymiotnika stanowi związek wyrazowy marksizm-leninizm) czy przygodowy + awanturniczy (w tym drugim adiektywie koniunkcja jest uwikłana znaczeniowo w sposób indywidualny, zupełnie obcy kompozycjom w rodzaju owocowo-warzywny; por. definicję w USJP: 'pełen niezwykłych, ryzykownych przygód, o powikłanej intrydze'). 
kanadyjsko-, jesienno- itp. jako komponencjalne formy fleksyjne; wystarczy wrócić do chwytu stosowanego (niestety niekonsekwentnie, od przypadku do przypadku) w SWarsz.

Zatem nie mnożąc haseł w siatce, dawać należy, właśnie w ślad za SWarsz., np. w artykule przymiotnikowym naukowy przykłady kompozycji z forma (funktorem nazwotwórczym) naukowo-: naukowo-filozoficzny, naukowo-weterynaryjny, naukowo-wychowawczy; w artykule przemysłowy odnotować wśród przykładów użycia przymiotnika hasłowego m.in. formacje: przemysłowo-gospodarczy, przemystowo-rolny; w psychiczny umieścić ilustracyjnie psychiczno-zmysłowy, w zoologiczny zoologiczno-anatomiczny itd. itp.

Nie można niby-wyrazom, kompozycjom przymiotnikowym typu owocowo-warzywny, nadawać statusu podhaseł w artykułach przymiotnikowych. Podhasłowe części artykułów hasłowych w słowniku konsekwentnie językowym nie są ani domeną tekstotwórstwa, ani domeną słowotwórstwa. SJPSzymcz. ma pod chemiczny podhasło chemiczno-fizyczny, pod historyczny - podhasło historyczno-literacki, pod matematyczny - podhasła matematyczno-fizyczny i matematyczno-przyrodniczy itd. Pod setkami innych przymiotników takich ,podhasel” na szczęście brak.

Interesujący, użyteczny poznawczo dla nielingwistów: historyków, kulturologów, socjologów, politologów i in. badaczy., zbiór kompozycyj typu informacyjno-doradczy, informacyjno-edukacyjny, informacyjno-poznawczy, informacyjno-reklamowy, informacyjno-wywiadowczy, owocowo-warzywny ${ }^{8}$ z niezwykle cenną, unikatową fotodokumentacją cytatową zawierają tomy zainicjowanej przeze mnie serii DLJP. Szczególnie dużo (foto)danych przyniosły woluminy $1-3$, opracowane po mistrzowsku przez P. Wierzchonia (por. Wierzchoń 2010-2012). Niewątpliwie małą rewolucją informacyjną, wprowadzenie do naukowego obiegu zupełnie nowej informacji leksykograficznej, będzie ukazanie się tomów 11-40 (tak!) do - jak zapowiada ich autor P. Wierzchoń - końca roku 2014. To, co podałem sam (pilotażowo) w SBJP, w odniesieniu do kompozycyj typu owocowo-warzywny jest zaledwie skromniutką zapowiedzią tej bez przesady gigantycznej masy danych, jaką środo-

${ }^{8}$ Przykładowa podseria zaczerpnięta z inspirującego indeksu Smółkowej (2001). 
wisko polonistów leksykografów otrzyma w tomach 11-40 (ale i następnych) serii DLJP.

\section{Wykaz skrótów}

DLJP - Depozytorium leksykalne jezzyka polskiego.

SBJP - Wawrzyńczyk J., 2000-2012, Stownik bibliograficzny języka polskiego. Wersja przedelektroniczna, t. 1-10, Warszawa: BEL Studio.

SJPDor. - Doroszewski W. (red.), 1958-1969, Stownik języka polskiego, t. 1-11, Warszawa: Wydawnictwo „Wiedza Powszechna”, Państwowe Wydawnictwo Naukowe.

SJPSzymcz. - Szymczak M. (red.), 1984, Stownik języka polskiego, t. 1-3, wyd. 4, Warszawa: Państwowe Wydawnictwo Naukowe.

SWarsz. - Karłowicz J., Kryński A. A., Niedźwiedzki W. (red.), 1900-1927, Słownik języka polskiego, t. 1-8, Warszawa: Nakładem Prenumeratorów, Wydawnictwo Kasy im. Mianowskiego.

SWil. - Zdanowicz A. i in., 1861, Stownik jęzka polskiego, t. 1-2, Wilno: Wydawnictwo Maurycego Orgelbranda.

USJP - Dubisz S. (red.), 2003, Uniwersalny stownik języka polskiego, t. 1-6, Warszawa: Wydawnictwo Naukowe PWN.

\section{Bibliografia}

SмóŁкоwa T., 2001, Neologizmy we wspótczesnej leksyce polskiej, Kraków: Wydawnictwo IJP PAN.

Wawrzyńczyk J., 2009, Autosuplement do Stownika warszawskiego, Poznań: Sorus.

WAWrzý́czyK J., 2010, Inny „,Doroszewski”, Łask: Oficyna Wydawnicza LEKSEM.

WaWrzyŃczyk J., 2011, Depozytorium leksykalne języka polskiego. Nowe fotomateriaty z lat 1901-2010, t. 8, Warszawa: BEL Studio.

WaWrzyńczyk J., 2012, Depozytorium leksykalne języka polskiego. Nowe fotomateriaty z lat 1901-2010, t. 10, Warszawa: BEL Studio.

WaWrzyŃczyK J., 2013, Instytutowi Języka Polskiego PANo «Popularnym poradniku BHP» z 1964 r. (Fotopamflet źródtoznawczy), [praca w przygotowaniu do druku].

Wierzchoń P., 2008, Fotodokumentacja, chronologizacja, emendacja. Teoria i praktyka weryfikacji materiatu leksykalnego w badaniach lingwistycznych, Poznań: Instytut Językoznawstwa UAM.

Wierzchoń P., 2010-2012, Depozytorium leksykalne języka polskiego. Nowe fotomateriaty z lat 1901-2010, t. 1-3, Warszawa: BEL Studio. 
WITAS P. K., 2012, Na przykład «prorosyjski»... Kartka z dziejów polskiej leksykografii teoretycznej i praktycznej, Warszawa: BEL Studio.

\section{A technico-lexicographic note on Polish composite words of owocowo-warzywny type}

\section{( s u m m a r y)}

The note discusses words such as owocowo-warzywny ('fruit and vegetable'), warzywno-owocowy ('vegetable and fruit'), naukowo-badawczy ('science-research') etc. which are very frequent in source texts on which lexicographers base their general dictionaries of Polish. The author examines the theoretical status of these expressions in selected Polish language dictionaries (with special reference to Słownik wileński and Słownik warszawski). 
